\title{
Contact Date
}

National Cancer Institute

\section{Source}

National Cancer Institute. Contact Date. NCI Thesaurus. Code C141005.

The date on which a direct or indirect interaction between individuals or org anizations occurred. 